\title{
Productivity and Blocking dalam Sistem Morfologi Bahasa Arab
}

\author{
${ }^{1}$ Zaqiatul Mardiah, ${ }^{2}$ Ahmad Khorin Junaedi \\ ${ }^{1,2}$ Program Studi Sastra Arab, Fakultas Sastra, Universitas Al Azhar Indonesia, Jalan Sisingamangaraja, \\ Kebayoran Baru Kompleks Masjid Agung Al Azhar Jakarta Selatan \\ Penulis untuk Korespondensi/E-mail: zaqiah@uai.ac.id
}

\begin{abstract}
Abstrak - Bahasa Arab adalah bahasa yang produktif, berdasarkan pada akar dan pola, dan sistem kata dan paradigma. Sehubungan dengan itu, penelitian ini bertujuan untuk mengungkap produktivitas formasi kata baru dalam bahasa Arab. Namun, dalam menggambarkan produktivitas, ada faktor pemblokiran yang berfungsi sebagai penghalang produktivitas. Penelitian ini menjelaskan dan menjelaskan bentuk atau pola yang keberadaannya diblokir oleh bentuk lain yang tidak mengikuti pola standar.

Penelitian ini merupakan penelitian kepustakaan yang menggunakan pendekatan kualitatif. Metode deskriptif digunakan dalam analisis data. Temuan dianalisis berdasarkan teori yang relevan. Ringkasan dari temuan tersebut adalah tujuan penelitian ini. Teori tentang qawaidul I'lal dari Al Ghulayaini (1994) dan Sulaiman (1995), di nahwu al asri, digunakan sebagai teori referensi dalam penelitian ini, sedangkan data diambil dari majalah Alo Indonesia edisi 104.

Hasil analisis menunjukkan bahwa bahasa Arab memiliki 7 jenis bentuk atau perubahan pola yang melanggar aturan wazan. Perubahan pola semacam ini menjadi faktor pembatas bagi generasi pola sebenarnya. Memang, pola ini adalah pola yang sering digunakan secara produktif. Dalam istilah bahasa Arab, pola tersebut dikenal sebagai qawa idul I'lal. Mereka adalah (1) $i$ la: $l$ bi al-qalb, ada dalam 124 kata, (2) i la: $l$ bi al-hadf, ada dalam 56 kata, (3) $i$ 'la: $l$ bi al-taskin adalah dalam 9 kata, (4) i la: $l$ bi al-naql ada dalam 21 kata, (5) i la: $l$ bi al-naql wa al-qalb ada dalam 27 kata, dan (6) i la : l bi al-naql wa al-hadf, ada dalam 10 kata, dan juga (7) 'i la: l bi al-naql wa al-qalb wa al-hadf ada dalam 1 kata.
\end{abstract}

Kata Kunci - Kata dan Paradigma, Morfologi, Produktivitas, Pemblokiran, I'lal

Abstract - Arabic is a productive language, based on root and pattern, and word and paradigm system. In relation to it, this research aims to reveal the productivity of new word formation in Arabic. However, in describing the productivity, there is a blocking factor that serves as a barrier for the productivity. This reseach describes and explains the forms or patterns whose existence are blocked by other forms which do not follow a standard pattern.

This research is a library research which use qualitative approach. The descriptive methods are used in the data analysis. Findings are analyzed based on the relevan theory. The summary of the findings are the goal of this study. Theory about qawaidul I'lal from Al Ghulayaini (1994) and Sulaiman (1995), in nahwu al asri, are used as a reference theory in this study, while the data are drawn from Alo Indonesia magazine 104 edition.

The results of analysis reveal that Arabic has 7 type of form or pattern change that violate the apply wazan rules. These kinds of pattern change become a block factor for the generation of the true pattern. Indeed, these patterns are the one that are frequently used in a productive way. In Arabic term, those pattern are well known as qawa-idul I'lal. They are (1) $i$ la:l bi al-qalb, exist in 124 words, (2) $i$ la:l bi al-hadf, exist in 56 words, (3) i la:l bi al-taskin is in 9 words, (4) i la:l bi al-naql is in 21 
words, (5) i la:l bi al-naql wa al-qalb is in 27 words, and (6) i la:l bi al-naql wa al-hadf, exist in 10 words, as well as (7) 'i la:l bi al-naql wa al-qalb wa al-hadf is in 1 word.

Keywords - Word and paradigm, morfologi, productivity, blocking, I'lal

\section{PENDAHULUAN}

\section{Latar Pokok Bahasan}

$\mathrm{D}$ alam konsep morfologi Hockket (1984), ada tiga sistem yang menjadi rujukan banyak bahasa di dunia, yaitu Item and Process (IP), Item and Arrangement (IA), dan Word and Paradigm (WP). Bahasa Arab dianggap menganut sistem yang terakhir, yaitu word and paradigm. Akar kata bahasa Arab yang sebagian besar terdiri dari 3 konsonan, dengan mengikuti pola-pola yang sedemikian rupa, dapat menghasilkan beragam bentuk baru, baik yang bersifat inflektif, maupun derivatif. Akar kata $/ \mathrm{k} \mathrm{t}$ b/ 'berkaitan dengan kegiatan menulis' dapat menghasilkan kata /ka:tib/ 'penulis', /kita:b/ 'buku', /kita:bah/ 'tulisan', /muka:tabah/ 'korespondensi', /maktab/ 'meja', /maktabah/ 'perpustakaan'. Sejumlah kata baru yang diderivasikan dari akar $/ \mathrm{k} \mathrm{t} \mathrm{b/} \mathrm{itu} \mathrm{dihasilkan}$ dari pola-pola baku, yang dalam bahasa Arab disebut dengan wazan.

Apabila dikaitkan dengan kajian Holes (1994) terhadap bahasa Arab, sistem morfologi bahasa Arab berbasis pada konsep root and pattern. Pattern atau wazan yang dimaksud adalah beberapa pola yang menjadi pedoman untuk diikuti setiap akar kata, sehingga masing-masing akar kata dapat menghasilkan sejumlah bentuk kata baru yang sama polanya, dan sama pula makna gramatikalnya.. Setiap kata yang ada dalam leksikon bahasa Arab sudah dapat dipastikan mengikuti salah satu pola dari 10 pola yang ada. Dalam konteks ini, bahasa Arab terbilang produktif, karena banyak sekali kata yang dapat dibentuk dari sebuah akar kata trikonsonantal dengan mengikuti pola yang ada. Namun, ada beberapa bentuk kata dalam bahasa Arab yang dalam proses pembentukannya tidak mengikuti wazan yang tersedia. Ada beberapa alasan yang dikemukakan terkait hal itu. Yang paling sering diungkapkan adalah alasan fonologis. Sebuah bentuk yang mengikuti pola tertentu dianggap menyulitkan penutur bahasa Arab ketika mengartikulasikannya, sehingga bentuk itu menjadi tidak berterima. Sebagai gantinya, ada bentuk lain yang sedikit keluar dari aturan pola yang ada. Kasus yang demikian dalam sistem morfologi disebut blocking.

Verba /ittasola/ adalah salah satu bentuk yang tidak mengikuti pola /ifta'ala/. Contoh di bawah ini akan memperjelas keterangan itu.

\begin{tabular}{|c|c|}
\hline akar & pola /ifta'ala/ \\
\hline /k s b/ & /iktasaba/ \\
\hline /f q r/ & /iftaqara \\
\hline$/ \mathrm{b} \mathrm{k} \mathrm{r/}$ & /ibtakara/ \\
\hline /b h l/ & /ibtahala/ \\
\hline /w s $1 /$ & /iwtasala/* $\rightarrow$ /ittasala/ \\
\hline /z k r/ & /iztakara/* $\rightarrow$ /izzakara/ \\
\hline
\end{tabular}

Dua contoh yang terakhir tidak dapat mengikuti pola yang ada. /iwtasala/ dan /iztakara/ adalah dua verba yang menurut penutur asli bahasa Arab tidak mudah diartikulasikan. Mereka lebih mudah melafalkan keduanya dengan /ittasala/ dan /izzakara/. Jika dianalisis lebih jauh, perubahan bentuk dari /iwtasala/ menjadi /ittasala/ dan perubahan dari /iztakara/ menjadi /izzakara/ dapat dijelaskan berdasarkan sistem morfofonologis bahasa Arab. Sistem morfofonologis tersebut, di kalangan ahli bahasa Arab, lebih dikenal dengan qawa-idul i'lal. Namun, yang ingin ditekankan dalam kajian kali ini adalah masalah produktifitas sebuah pola dalam menghasilkan bentuk-bentuk baru, serta kemungkinan tidak berterimanya sebuah bentuk yang mengikuti pola tertentu karena terkait dengan faktor blocking.

\section{Tujuan Penelitian}

Kajian ini hendak mengungkap fenomena produktifitas pembentukan kata baru dalam bahasa Arab yang menganut sistem akar dan pola. Namun, dalam mendeskripsikan produktifitas tersebut, ada faktor blocking yang menjadi penghalang produktifitas itu sendiri. 


\section{Rumusan Masalah}

Berdasarkan uraian pada sub-bab sebelumnya, penelitian ini hendak memetakan proses pembentukan kata bahasa Arab yang terkait dengan produktifitas dan faktor yang menghalangi produktifitas itu. Dengan kajian ini, pertanyaan tentang pola-pola yang produktif serta pola yang tidak dapat diterapkan pada sebuah akar kata akan terjawab. Selain itu, problem tentang pola-pola yang tidak berterima pada akar kata-akar kata tertentu akan dijelaskan secara detail penyebabnya dan analisisnya.

\section{Kontribusi Penelitian}

Riset ini akan memberikan gambaran tentang seberapa produktif sebuah pola ketika ia diterapkan ke banyak bentuk dasar atau akar. Ketika sebuah pola tidak dapat diterapkan pada sebuah bentuk dasar, ini menjadi bagian penting dalam kajian bolcking yang belum begitu populer di kalangan peminat bahasa Arab. Dengan demikian, topik ini akan melengkapi kajian i'lal yang sudah banyak dibahas dalam literatur gramatika Arab.

\section{Metode Penelitian}

Dengan menggunakan pendekatan kualitatif, riset ini bersifat library research. Metode penelitian dan analisis data berbentuk deskriptif, menyajikan temuan yang dianalisis berdasarkan teori yang ada, serta menyimpulkan temuan tersebut sebagai hasil akhir dari kajian ini.

\section{Data dan Sumber Data}

Data penelitian ini adalah semua bentuk kata yang ada dalam majalah "Alo Indonesia" vol 108, edisi Mei-Juni 2014. Masing-masing bentuk tersebut akan dianalisis asal-usulnya, sehingga akan ditemukan mana bentuk yang mengikuti pola, dan mana pula yang tidak mengikuti pola. Bentukbentuk yang tidak mengikuti pola tersebut adalah bentuk yang memblock kemunculan bentuk yang mengikuti pola.

\section{TINJAUAN PUSTAKA}

\section{Pengantar}

Topik tentang productivity and blocking tidak begitu populer di kalangan linguist Arab. Namun, ada kajian yang lebih kurang sama dengan sistem morfologi bahasa Arab, yaitu apa yang sering disebut dengan i'lal. I'lal adalah sebuah kajian tentang perubahan sebuah bentuk kata menjadi menjadi bentuk lain dengan cara mengganti fonem yang sakit /? w y/, melesapkan fonem, atau dengan cara mengubah suku kata terbuka menjadi suku kata tertutup (Kholisin, 2001: 85)

\section{Kholisin (2001)}

Kholisin di dalam tesisnya yang berjudul "Asimilasi dalam Bahasa Arab" sebuah kajian "Morfofonologi" menjelaskan bahwa i lal adalah sebuah proses modifikasi huruf illah (semivokal) dengan cara melesapkan, mengganti, atau menukar tempat (metatesis). Selain itu, Kholisin juga menjelaskan tentang macam-macam $I \backslash l \pm l$ yang terbagi menjadi tiga macam, yaitu: $a l-i 1$ bi al-qalb, al-'ilal bi al-hazf, al-'ilal bi altaskin.

Namun, pada tesis yang ditulisnya. I lal tidak dijelaskan secara detail. Ia hanya membahasa tema itu secara garis besarnya saja. Selain itu, dalam tesis tersebut tidak ditemukan alasan yang berdasarkan pada kajian fonologi. Ia hanya mengacu pada kaidah-kaidah yang tertera dalam rujukan berbahasa Arab yang kemudian diberikan contoh di setiap bagiannya.

Kholisin juga menjelaskan bahwa I'lal masuk kedalam kajian Assimilasi. Karena secara sekilas, kaidah yang digunakan dalam kajian i lal sama dengan kaidah yang berlaku dalam kajian Assimilasi.

\section{Taqiyah (2008)}

Aminatut Taqiyah dalam skripsinya yang berjudul " Al-'Tlal wa Al-'Ibdal fi Sarah Al'Ahqaf (Dirasah Tahliliyah harfiyyah) menjelaskan bahwa $i$ lal adalah perubahan yang terjadi pada huruf illah guna meringankan pengucapan dengan cara menukar, melesapkan vokal dan melesapkan huruf illah. Penelitian yang dilakukan oleh Aminah adalah meneliti kata-kata yang masuk ke dalam kategori $i$ lal dan ibdal yang terdapat dalam surat Al-Ahqaf.

Adapun mengenai pembagian macam-macam i lal, Aminah menjelaskan bahwa i lal dalam bahasa Arab hanya ada tiga macam, yaitu: al'i $l \pm l$ bi al-qalb, al-'i $l \pm l$ bi al-¥adf, al-'i $l \pm l$ bi altask $^{3} n$. Dalam karyanya, Aminah juga 
menjelaskan pembagian verba berdasarkan hurufnya yang terbagi menjadi dua yaitu Fi'lun $\not a ¥^{3} h$ dan Fi'lun Mu’tal. Dia juga menjelaskan bahwa Fi'lun Mu`tal terbagi menjadi tiga yaitu $M i £ \pm l, A j w \pm f$ dan $N \pm q i s$. Ketiga kategori Fi lun $M u ` t a l$ tersebut lah yang berperan penting dalam kajian $i$ 'lal.

\section{Irawan (2011)}

Tesis yang dilakukan oleh Irawan membahas tentang ibdal dalam bahasa Arab menurut pandangan linguis modern. Menurutnya, bahasa Arab memiliki karakter morfologi yang kuat yaitu berdasarkan pada konsonan dan pola dalam pembentukan sebuah kata yang kemudian keduanya diterapkan dalam model tulisan dua baris alfabet, yaitu bunyi konsonan yang kemudian diikuti dengan tanda-tanda vokal. Irawan juga mengatakan bahwa pembentukan suatu verba dalam bahasa Arab terdiri dari unsur konsonan dan unsur semivokal.

Semua kata yang terbentuk dalam bahasa Arab sudah pasti sesuai dengan pola-pola yang sudah ditentukan dalam bahasa Arab. Namun, untuk kata yang terdiri dari unsur semivokal maka akan mengalami perubahan bentuk dengan pola yang berlaku. Oleh karena itu kajian yang bersangkutan tentang kata yang terdiri dari unsur semivokal adalah i lal yaitu proses pergantian ي dan saling menggantikan antara semivokal ( 1 ) dan hamzah dalam bahasa Arab pada verba trilateral atau pada nomina dari verba tersebut.

Untuk penelitian yang dilakukan Irawan. Menurutnya semua bagian dari i lal masuk ke dalam ibdal. Padahal jika ditinjau dari beberapa pendapat para ahli bahasa, bahwa i lal dan bagian-bagiannya merupakan kajian tersendiri dalam bahasa Arab.

Pada intinya, menurut Irawan. Kajian i lal termasuk ke dalam kajian ibdal. Karena jika dilihat secara kaidah, tidak ditemukan perbedaan. Hanya saja i lal mengkaji khusus verba atau nomina yang di dalamnya terdapat huruf illat atau semivokal.

\section{Michael (2013)}

Sebuah kajian tentang productivity dalam sistem morfologi bahasa Inggris, pernah dilakukan pada tahun 2013 oleh Michael. Ia berfokus pada proses morfologi bahasa Inggris (sufiks dan bentukbentuk yang berkombinasi). Ia ingin melihat apakah afiksasi sufiks dan kombinasi kata adalah proses morfologis yang paling produktif dalam sistem morofologi bahasa Inggris, baik secara sinkronis, maupun diakronis. Namun, dalam riset Michael ini, tidak disinggung masalah blocking

\section{KERANGKA TEORI}

\section{Proses Morfologis}

Dalam pembentukan suatu kata dalam sebuah bahasa akan terjadi proses pendukung yang dinamakan dengan proses morfologi.

Menurut Chaer (2012:177) dalam bukunya Linguistik Umum, proses morfologi adalah proses pembentukan kata dari sebuah bentuk dasar melalui cara afiksasi, reduplikasi, komposisi, konversi, modifikasi internal, dan akronimi. Selain itu, mengenai proses morfologi Verhaar dalam karyanya Asas-asas Linguistik Umum (2010) memiliki pendapat lain. Menurutnya proses morfologi adalah proses pembentukan kata melalui cara afiksasi, klitisisasi, derivasi, reduplikasi, dan komposisi.

Pendapat lain mengenai proses morfologi juga dikemukakan oleh Hidayatullah (2012:76) yaitu, beberapa kata beru terbentuk melalui proses penggabungan dua kata atau lebih yang dapat terwujud ke dalam beberapa perpaduan yaitu: Afiksasi, pemajemukan, akronim, pembentukan susut, abreviasi, dan paduan.

Dari sekian banyak penjelasan mengenai proses morfologi yang telah dikemukakan oleh beberapa ahli bahasa. Bahasa Arab memiliki proses yang sedikit berbeda dan memiliki kekhasan tersendiri dibandingkan dengan bahasa lain. Haywood (1965:1) menyatakan bahwa suatu kata dalam bahasa Arab memiliki kekhasan berupa konsonan dan akar katanya pada umumnya terdiri dari tiga huruf asli (trikonsonantal) yaitu konsonan pertama (K1), konsonan kedua (K2), dan konsonan ketiga (K3). Selain itu, ada juga yang terdiri dari empat huruf asli (kuadrikonsonantal) dimana untuk (K4) merupakan hasil pengulangan dari (K3). 


\begin{abstract}
Akar dan Pola
Dalam bahasa Arab, yang disebut akar adalah 3 atau 4 konsonan berderet yang menjadi "bentuk" awal dari bentuk-bentuk derivasional lainnya. Adapun pola adalah sebuah format baku yang menyerupai bentuk kata, yang di dalamnya terdapat akar trikonsonantal dan atau konsonan tambahan, yang menjadi patokan dalam membentuk kata-kata lainnya. Format tersebut sudah permanen sifatnya, sehingga akar trikonsonantal dapat diubah bentuknya dengan mengikuti pola yang sudah ada, menjadi kata baru, baik yang derivatif, maupun inflektif.
\end{abstract}

Sebagai contoh adalah kata jalasa 'duduk' yang mempunyai akar JLS. Dari akar ini nantinya akan diderivasikan dan diinfleksikan menjadi banyak kata melalui pola-pola yang sudah ada dalam bahasa Arab. Dari akar JLS ini, akan diperoleh kata baru, yaitu ja:lisun (mengikuti pola /fa: 'ilun/), majlisun (mengikuti pola /mafilun/) dan lain sebagainya. Semua perubahan itu tidak terlepas dari proses afiksasi dan modifikasi internal.

\section{Production and Blocking}

Kata dalam bahasa Arab pada hakikatnya terdiri dari tiga konsonan asli sebelum dibubuhi afiks. Setiap kata baik itu verba atau nomina memiliki aturan pola atau wazn yang harus diterapkan ketika kata tersebut diproduksi. Untuk kategori kelas verba pada umumnya terdiri dari tiga sampai empat konsonan asli yang terbagi menjadi dua yaitu: al-fi'lu al-sahih dan al-fi'lu al-mu`tal.

Pada sub bab sebelumnya telah disebutkan bahwa setiap kata dalam bahasa Arab harus mengikuti pola atau wazn yang baku. Namun, Untuk kata yang terdiri dari unsur semivokal atau al-fi 'lu almu`tal akan mengalami sedikit "penyimpangan" dari pola yang berlaku. Sebagai contoh adalah

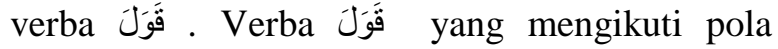
/fa'ala/ tidak digunakan dalam bahasa Arab. Penggantinya adalah verba قَالَ. Kemudian, jika verba tersebut mengikuti pola sَفْعُوْل

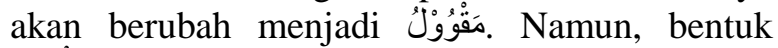
صَقْوُونُ bentuk lain yang lebih produktif digunakan yaitu مَقُوْنُ Proses seperti ini oleh Jensen disebut dengan proses blocking (1995: 89). Artinya, bentuk yang "menyimpang" dari pola yang baku menjadi lebih produktif digunakan. Dalam kasus ini, pola yang tidak baku tersebut memblok produktifitas pola yang baku.

\section{الإعلال /al-'i lal/}

Secara etimologis, kata الإعلال merupakan hasil

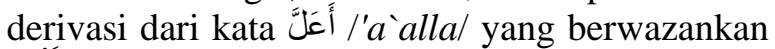
أَفْعَلَ /'af alal. Adapun arti dari i'lal itu sendiri menurut Munawwir (1997:965) adalah menimpakan penyakit.

Huruf illat menurut Sayuti (2012:35) memiliki fungsi sebagai vokal panjang. Di mana vokal panjang ini selalu dipasangkan dengan tiga vokal yang ada dalam bahasa Arab. Vokal /a/ disandingkan dengan vokal panjang //, vokal /i/ disandingkan dengan vokal panjang /ي/, dan vokal /u/ disandingkan dengan vokal panjang /و/.

Adapun arti huruf illat dalam kamus Hans Wehr (1967:633) adalah 'the weak letters' yaitu huruf yang lemah. Huruf ini dikatakan lemah karena dianggap sebagai pengganggu dan berbeda dengan konsonan. Huruf illat sering kali mengalami berbagai peristiwa fonologis, seperti perubahan dan pelesapan.

Secara istilah Fayyadh (1995: 273) mengatakan: الإعلال هو تغيير يحدث في الهززة أو أحد أحرف العلة: الألف،

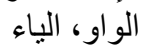

I al-'Tlal huwa tagy'run yahdu£ fi al-hamzah 'aw 'ahad 'ahruf al-'illah: al-'alif, al-waw, al-yal I lal adalah perubahan yang terjadi pada hamzah atau salah satu huruf illat (ا، و، ي)'.

Perlu diketahui pula bahwa verba dalam bahasa Arab jika dilihat dari segi hurufnya terbagi menjadi dua, yaitu: (1) fi l Sohih dan (2) fi l mu'tal. Fi'l shahih adalah verba yang di dalamnya tidak terdapat huruf illat, sedangkan fi l mu'tal adalah verba yang di dalamnya terdapat satu atau dua huruf illat. Adapun untuk fi'l mu'tal itu sendiri dibagi menjadi empat bagian yaitu: (1) missal, yaitu verba yang disusun oleh huruf illat pada K1, (2) ajwaf, yaitu verba yang disusun oleh huruf illat pada K2, (3) naqis yaitu verba yang disusun oleh huruf illat pada $\mathrm{K} 3$, dan (4) lafif, yaitu verba yang disusun oleh huruf illat pada K1 dan K2, serta K1 dan K3.

Fayyadh (1995: 273) menyatakan bahwa ilal terbagi menjadi 7 yaitu: (1) al-'ilal bi al-qalb, 
(2) al-'i lal bi al-taskin, (3) al-'i lal bi al-hazf, (4) 'i lal bi al-naql, (5) 'i lal bi al-qalb wa al-naql, (6) 'i lal bi al-hazf wa al-naql dan (7) 'i lal bi alqalb wa al-naql wa al-hazf.

\section{A-'i lal bi Al-Qalb (Melalui Perubahan)}

I lal bi Al-Qalb yaitu mengubah salah satu huruf illat dengan huruf illat lainnya atau dengan konsonan. Al-Ghalayain dalam karyanya Jami Al-Dur-s Al-`Arabiyyah membagi i lal bi al-qalb menjadi enam bagian yaitu:

1. Perubahan / و / / / dan / / / / / / /

2. Perubahan $/$ / / $/$ menjadi /

3. Perubahan / / / وا Penjadi.

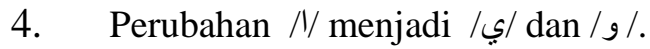

5. Perubahan hamzah / / / / menjadi / / / / dan Iو/.

6. Perubahan / dan / و / menjadi hamzah / /

\section{Al-'i lal bi Al-Hazf (Melalui Pelesapan)}

Ilal bi al-hazf adalah melesapkan atau menghilangkan semi vokal yang terdapat pada suatu kata dalam bahasa Arab. Al-Ghalayain (2008:312-313) mengatakan bahwa proses pelesapan semivokal ( او و dan dan juga hamzah /ء / dapat terjadi jika:

a. $\quad / g /$ sebagai K1 pada verba imperfektum berpola yafilu dan verba imperative dengan pola if il.

b. / / / / / sebagai K2 yang tidak bervokal dan bersandingan dengan K3 yang tak bervokal.

c. // sebagai K2 yang tidak bervokal dan bersandingan dengan K3 yang tidak bervokal.

d. / / / dan sebagai K3 pada verba imperatif.

e. / / / / dan sebagai K3 dan bersanding dengan / gama`ah.

f. // berperan sebagai hamzah wasl yang jatuh setelah prefix

g. $\mid \& /$ berperan sebagai prefiks dan jatuh setelah prefix lainnya.

h. $/ \& /$ berperan sebagai K2 dan bersanding dengan semivokal yang berposisi sebagai K3.

\section{Al-'i lal bi Al-Taskin (Pelesapan vokal)}

I lal bi Al-Taskin adalah proses pelesapan vokal yang terdapat pada huruf illat. Al-Ghalayain
(2008) pada karyanya $J \pm m i ` A l-D u r-s \quad A l$ Arabiyyah menerangkan bahwa proses pelesapan vokal pada huruf illat terjadi jika / $/$ dan اي/ sebagai K3 yang jatuh setelah vokal /i/ atau vokal /u/.

\section{Al-'i lal bi Al-Naql (Melalui Pemindahan Vokal)}

I lal bi al-naql adalah proses pemindahan vokal yang mengiringi huruf illat ke konsonan sebelumnya yang tak bervokal (Hasan 1974: 757). Proses ini dapat terjadi jika / و / dan sebagai K2 dan keduanya jatuh setelah konsonan tak bervokal. Maka vokal yang mengikuti semivokal dipindahkan ke konsonan sebelumnya.

I lal bi Al-qalb wa Al-Naql (melalui Perubahan dan Pemindahan Vokal)

'i lal bi al-qalb wa al-naql adalah proses pemindahan vokal yang mengiringi huruf illat yang kemudian dilanjutkan dengan perubahan huruf illat tersebut dengan huruf illat yang lainnya.

Menurut Fayyadh (1995: 280) dalam karyanya Al-Nahwu Al-`Asri menjelaskan. Bahwa proses seperti ini terjadi jika:

a. / / / dan bervokal /a/ dan berposisi sebagai K2 sedangkan sebelumnya merupakan K1 tak bervokal. Vokal yang yang mengikuti / / atau اي/ harus dipindahkan ke konsonan sebelumnya dan semivokal tersebut berubah fungsi sebagai vokal panjang dari vokal /a/. Kemudian / / / dan / harus diubah menjadi //.

b. /g/ bervokal /i/ dan berposisi sebagai K2 sedangkan sebelumnya merupakan K1 tak bervokal sehingga vokal yang yang mengikuti harus dipindahkan ke konsonan sebelumnya dan semivokal tersebut berubah fungsi sebagai vokal panjang dari vokal /i/, sehingga /g/ harus diubah menjadi /ي

\section{Ilal bi Al-Hazf wa al-Naql (Melalui Pemindahan Vokal dan Pelesapan Semi Vokal) \\ ilal bi Al-hazf wa al-naql adalah proses pemindahan posisi vokal yang mendapingi huruf illat. Kemudian dilanjutkan dengan adanya proses pelesapan huruf illat dikarenakan}


berdampingan dengan konsonan tak bervokal setelahnya.

Menurut Fayyadh (1995), peristiwa seperti ini dapat terjadi jika / / / dan / bervokal, menempati posisi $\mathrm{K} 2$ dan terletak di antara dua bunyi tak bervokal.

Ila l bi Al-Naql wa al-Qalb wa al-Hazf (Melalui Pemindahan Vokal, Perubahan dan Pelesapan Semi Vokal)

Ilal bi Al-naql wa al-qalb wa al-hazf adalah proses pemindahan vokal yang mengiringi huruf illat yang kemudian dilanjutkan dengan perubahan dan pelesapan semivokal.

Jika dianalisis, peristiwa seperti ini terjadi jika / dan / bervokal menempati K2 pada fi il amr

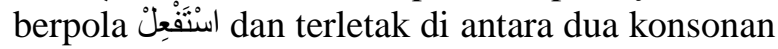
asli yang tak bervokal.

\section{Productivity and Blocking}

\section{Productivity}

Di dalam ilmu shorof, ada 10 pola verba dasar bahasa Arab yang sering digunakan dalam komunikasi sehari-hari. Disebut demikian, karena sebagian besar kosakata bahasa Arab berasal dari 10 pola tersebut. Sepuluh pola itu adalah /fa'ala/, /fa''ala/, /?af'ala/, /fa:'ala/, /tafa''ala/, /tafa:'ala/, /ifta'ala/,/infa'ala/, /if'alla/, dan /istaf'ala/. Sembilan pola yang terakhir, sering disebut verba derivasional, karena merupakan verba yang dihasilkan karena proses derivasi dari pola satu /fa'ala/ yang berupa akar trikonsonantal. Selain menjadi verba derivasional, masing-masing verba tersebut akan diderivasikan lagi untuk menghasilkan kata baru dengan makna leksikal dan gramatikal yang baru. Pola-pola derivatif dari verba ini dapat dikatakan produktif diterapkan pada banyak kosakata bahasa Arab secara umum.

Pada hakikatnya, semua pola verba dasar bahasa Arab yang tersusun dari akar trikonsonantal yang "sehat" dapat disebut produktif menghasilkan kata baru. Konsonan sehat yang dimaksud adalah konsonan yang bukan //, / / / / Namun, ada satu pola atau verba dasar yang memang tidak banyak menghasilkan kata baru, yaitu /if'alla/.
Dikatakan demikian, bukan karena ketidakmampuan kosakata untuk diterapkan pada pola ini, melainkan karena kosakata yang mengikuti pola ini memang jumlahnya terbatas.

\section{Blocking}

Dalam bahasa Arab, verba dasar yang tersusun dari akar trikonsonantal "sakit" memang menjadi problema tersendiri. Hal itu disebabkan banyaknya proses perubahan bentuk kata yang tidak konsisten, atau yang tidak sesuai dengan pola dan kaidah yang standar dan baku. Fenomena yang demikian, dalam kajian linguistik secara umum disebut blocking, karena pola atau kaidah yang baku tidak digunakan, tetapi menggunakan pola atau kaidah yang lain. Kasus yang demikian, sering kali menyulitkan para pembelajar bahasa Arab dalam memahami sistem morfologi bahasa Arab.

Namun demikian, ketidakkonsistenan tersebut, jika dicermati tetap ada aturannya. Aturan atau kaidah tentang pola-pola yang tidak konsisten itulah yang terangkum dalam analisis I'lal berikut.

\section{Al-i lal bi Al-Qalb}

Pada bab sebelumnya penulis telah memaparkan bahwa al-i lal bi al-qalb terbagi menjadi enam bagian yaitu: (1) Perubahan / / / dan / menjadi

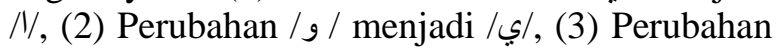

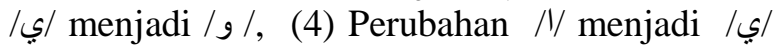

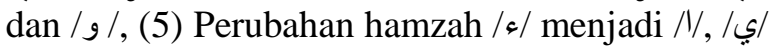
dan / / / dan (6) Perubahan / dan / و/ menjadi hamzah $/ \varsigma /$.

\section{Perubahan و / / / / / / / / / / / / /}

Perubahan / / dan / / menjadi /// dapat terjadi pada beberapa kasus sebagai berikut:

a. / / / / danenempati K2 pada verba ma:di yang berpola fa ‘ala dan ifta ‘ala, serta pada verba muda:ri berpola yafta ilu yang sebelumnya terdapat konsonan yang bervokal $/ \mathrm{a} /$.

b. / / / / dan / menempati K3 pada verba ma:di yang berpola fa ala, istaf ala, dan af ala, serta pada verba muda:ri pasif di mana sebelumnya terdapat konsonan bervokal /a/. 
Ada beberapa kata yang penulis temukan pada beberapa rubrik dalam majalah Alo Indonesia no.108, yaitu:

Tabel 1. Kata-Kata yang Penulis Temukan di Rubrik Majalah ALO no.108 Perubahan/و/ / dan / menjadi /l/

\begin{tabular}{|c|c|c|}
\hline No & Bentuk asli & Halaman \\
\hline 1 & زَالَ /za:lal / & $\begin{array}{c}\text { hlm. } 8 \text {, kolom } \\
1 \text { baris } 3\end{array}$ \\
\hline 2 & |tahta:ju/ & $\begin{array}{c}\text { hlm. } 11, \\
\text { kolom } 1 \text { baris } \\
1\end{array}$ \\
\hline 3 & تَنْسَى /tansa/. & $\begin{array}{l}\text { hlm. 7, kolom } \\
3 \text { baris } 3\end{array}$ \\
\hline
\end{tabular}

زَآَ ja:lal dalam (1) merupakan morfem dasar yang berasal dari akar kata زول/ZWL/ yang berpola fa ala (Taher 2011: 181). Jika mengikuti pola yang berlaku, dari akar زول /ZWL/ seharusnya dapat menghasilkan morfem dasar

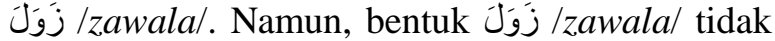
ditemukan dalam bahasa Arab melainkan diblok oleh kata زَza:lal. Pada kasus itu yang terjadi adalah perubahan konsonan /g/ menjadi pemanjangan vokal /a/ pada K1. Hal ini dapat terjadi karena dalam fonologi bahasa Arab konsonan /w/ yang menempati K2 dan didahului vokal /a/, harus diganti dengan pemanjangan vokal /a/ tersebut.

تحْنَاجُ Itahta:jul dalam (2) merupakan verba muda:ri dari bentuk ma:di احَتَّاجَ lihta:jal. Adapun verba احْتَاجَ /ihta:jal merupakan hasil derivasi dari morfem dasar حَاجَ /ha:jal yang juga memiliki akar kata ح و ج /HWJ/ (Taher 2011: 96). Akar tersebut mengikuti pola yafta ìlu sehingga menjadi تحَتْنَتِجْ Itahtawijul tidak diizinkan muncul karena kehadiran bentuk تحْنَاُْج /tahta:ju/. Proses

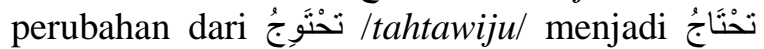
Itahta:jul, dikarenakan posisi /w/ yang menempati K2 serta terletak setelah vokal /a/ tidak berterima dalam artikulasi bahasa Arab dan harus diubah menjadi vokal panjang untuk /a/.

Verba تنسى /tansa:/ dalam (3) merupakan verba muda:ri dari bentuk ma:di نَبَيَّin /nasiyal yang memiliki akar ن س ي/NSY/ (Taher 2011: 420). Dengan mengikuti pola tafalu, seharusnya verba itu menjadi تَنَسْنَ /tansayu/. Namun, bentuk / تَنْسَيُ oleh para ahli bahasa Arab, melainkan menggantinya dengan bentuk تَنَسَى /tansa:/. Pada kasus ini, yang terjadi adalah perubahan konsonan اي/ menjadi pemanjangan vokal /a/ pada K2. Ini dapat terjadi karena dalam fonologi bahasa Arab, konsonan /w/ yang menempati K3 dan didahului oleh vokal /a/, harus diganti dengan pemanjangan vokal /a/ tersebut.

\section{/ Perubahan / Menjadi /}

Sebagaimana yang telah penulis paparkan pada bab sebelumnya. Perubahan / / menjadi dapat terjadi pada beberapa keadaan sebagai berikut:

a. $\quad / g /$ sebagai K1 dan terletak setelah vokal /i/ yang berpola mif $\pm l u n$.

b. $/ g /$ sebagai K2 dan terletak setelah vokal /i/ yang berpola fi ${ }^{`} \pm$ lun dan fi \pm latun.

c. $/ g /$ sebagai K3 dan terletak setelah vokal /i/ yang berpola fa ilun dan fa ila.

d. $\quad /$ / / terletak setelah / tasgi:r.

e. / / / sebagai K2 pada jamak taksir yang berpola af \pm lun serta didahului oleh konsonan / /

f. $\quad /$ / / sebagai K2 dan berdampingan dengan / / pada pola fay ilun dan fi latun.

Penulis menemukan beberapa kata dalam majalah Alo Indonesia yang dapat dianalisa, di antaranya adalah:

Tabel 2. Kata-Kata yang Penulis Temukan di Rubrik /ي/ Majalah ALO no.108 Perubahan و و Menjadi

\begin{tabular}{ccc}
\hline No & Bentuk asli & Halaman \\
\hline 4 & /mi:la:d/ ميلاد & $\begin{array}{c}\text { hlm. 6 kolom } \\
\text { 2 baris 16 }\end{array}$ \\
\hline 5 & $\begin{array}{c}\text { /ziya:rah/ } \\
\text { /2lm. 6 kolom } \\
1 \text { baris 6 }\end{array}$ \\
\hline 6 & /ayya:m/ أيام. & $\begin{array}{c}\text { hlm. 15 kolom } \\
1 \text { baris 5 }\end{array}$ \\
\hline
\end{tabular}

Nomina مِيْلَد /mi:la:d/ dalam (4) merupakan derivasi dari bentuk ma:di وَلَكَ /waladal yang memiliki akar و و ل د/WLD/ (Taher 2011: 477). Akar tersebut apabila mengikuti pola mif a:lun akan menjadi مِوَ لَاد /miwla:d/. Namun, bentuk مِوَ لَّاد /miwla:d/ tidak dimunculkan karena diblok oleh kata مِيْلَد /mi:la:d/. Pada kasus ini, yang 
terjadi adalah perubahan konsonan $/ g$ menjadi pemanjangan vokal /i/ pada prefix. Hal tersebut dapat terjadi karena konsonan /w/ yang menempati K1 dan didahului oleh vokal /i/ harus diganti dengan pemanjangan vokal /i/ tersebut, sehingga terciptalah bentuk مِيْلَداد/mi:la:d/.

زَيَارَة /ziya:rah/ dalam (5) merupakan bentuk

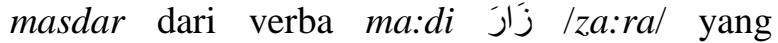
memiliki akar زور /ZWR / (Taher 2011: 180). Nomina tersebut mengikuti pola fi a:latun sehingga seharusnya menjadi زوَارَّة /ziwa:rah/. Namun, bentuk زَوَارَة /ziwa:rah/ tidak diizinkan muncul karena kehadiran bentuk زَوِيَارَةziya:rah/. Pada kasus itu, yang terjadi adalah perubahan konsonan /w/ menjadi konsonan /y/. Hal ini dapat terjadi karena dalam fonologi bahasa Arab, konsonan /w/ yang menempati K2 dan didahului vokal /i/ harus diganti dengan konsonan /y/.

Kata أَيَّام /'ayya:m/ dalam (6) merupakan bentuk jamak taksir dari bentuk tunggal يَوْمُ /yawmun/ (Munawwir 1997: 1591). Bentuk tunggal tersebut mengikuti pola afa:lun sehingga seharusnya أَيْوَام أَيْوَام /'aywa:m/. Namun, bentuk /'away: $m /$ tidak disepakati oleh para ahli bahasa Arab, melainkan menggantinya dengan bentuk أيَّام /'ayya: $\mathrm{m} /$. Hal ini dapat terjadi karena posisi /w/ yang menempati K2 serta terletak setelah konsonan /y/ tidak berterima dalam artikulasi bahasa Arab sehingga konsonan /w/ harus diganti dengan konsonan /y/. Adapun hasil akhirnya adalah terciptanya kata 'ayya:m.

\section{/و}

Perubahan $/$ menjadi / / dapat terjadi pada beberapa keadaan sebagai berikut:

a. اي/ sebagai K1 pada verba muda:ri yang terletak setelah vokal /u/ dengan pola yufilu.

b. اي/ sebagai K1 terletak setelah konsonan bervokal /u/ pada pola mufilun.

c. اي/ sebagai K2 terletak setelah vokal /u/ pada pola fu'laa.

d. اي/ sebagai K3 pada pola fa laa, pada verba ma:di berpola fa ula

e. اي/ / terletak sebelum / nisbah.

Ada satu kata yang ditemukan dalam majalah Alo Indonesia edisi 108:
Tabel 3. Kata-Kata yang Penulis Temukan di Rubrik / و/ Majalah ALO no.108 Perubahan /ي /

\begin{tabular}{ccc}
\hline No & Bentuk asli & Halaman \\
\hline 7 & \multirow{1}{*}{$/$ sa:nawiyyah/ } & $\begin{array}{c}\text { hlm. } 16 \text { kolom 1 } \\
\text { baris 5 }\end{array}$ \\
\hline
\end{tabular}

Kata ثَانَنِيَة //sa:nawiyyah/ dalam (7) merupakan bentuk nisbah dari bentuk ثَانَيْي /sa:niyun/ serta merupakan ism jamid. Kata tersebut mengikuti pola fa: 'aliyyah sehingga seharusnya menjadi ثَانَيَيَّة /sa:nayiyyah/ tidak diizinkan muncul karena kehadiran ثَانَوَيَّة //sa:nawiyyah/. Proses perubahan dari ثَانَوِيَة /sa:nayiyyah/ menjadi /sa:nawiyyah/ disebabkan posisi /y/ yang menempati K3 serta diiringi oleh /y/ nisbah, sehingga /y/ harus diganti dengan konsonan /w/. Hasilnya adalah terciptanya bentuk sa:nawiyyah.

\section{/ي/ Perubahan // menjadi / / dan}

Berikut ini adalah beberapa syarat yang harus dipenuhi untuk perubahan // menjadi s/ atau $\mid g$ : :

a. /// sebagai K2 dan didahului vokal /u/ pada verba ma:di majzum

b. // terletak setelah / tasgi:r.

c. // terletak setelah vokal /i/ pada jama taksir dengan pola mafa: 'iilu dan fa`a:'ilu.

d. // menempati konsonan akhir pada musanna:

Berikut adalah analisis data yang penulis temukan dalam beberapa rubrik di majalah Alo Indonesia edisi 108:

Tabel 4. Kata-Kata yang Penulis Temukan di Rubrik Majalah ALO no.108 Perubahan /// menjadi / / / dan اي/

\begin{tabular}{|c|c|c|}
\hline No & bentuk asli & halaman \\
\hline 8 & / شَوَاطِئ /syawa:ti' & $\begin{array}{c}\text { hlm. } 6 \text { kolom } 1 \\
\text { baris } 3\end{array}$ \\
\hline 9 & أمُوَال & $\begin{array}{c}\text { hlm. } 20 \text { kolom } 2 \\
\text { baris } 7\end{array}$ \\
\hline
\end{tabular}

Kata شَوَاطِئ /syawa:ti\% dalam (8) merupakan sigah muntaha: al-jum dari bentuk tunggal شَاطِئ /sya:ti $\%$ Bentuk tunggal tersebut mengikuti pola fa'a:'ilu sehingga menjadi شَالطِئ Namun, bentuk شَالطئ 
شَوَاطِئُ /syawa:ti \% Pada kasus itu, yang terjadi adalah perubahan vokal panjang /// menjadi /w/. Ini dapat terjadi karena dalam fonologi bahasa Arab, adanya dua // yang berurutan tidak berterima dalam artikulasi bahasa Arab dan sulit diucapkan, sehingga salah satu // harus diganti dengan konsonan $/ \mathrm{w} /$, hal ini disebabkan terdapat vokal /a/ sebelum /\%. Hasilnya adalah bentuk yang sebelumnya شَوَاطِئ Bَاطِئ berubah menjadi /syawa:ti $\%$

Kata أَمْوَال /'amwa:l/ dalam (9) merupakan jama taksir dari bentuk tunggal مَال /ma:l/. Bentuk tunggal tersebut mengikuti pola af a:lun sehingga menjadi kata أمَأل. Namun, yang lebih produktif digunakan adalah kata أَمْوَال /'amwa:ll.

Proses perubahan dari أَمْوَال /'amwa:ll menjadi أَمْوَال /'amwa:l/ karena posisi alif /// yang terletak di antara vokal /a/ dan alif //, sehingga // harus diganti dengan konsonan /w/ yang kemudian diiringi dengan vokal /a/ agar /// dapat difungsikan sebagai vokal panjang /a/. Hasilnya adalah adanya bentuk أَمْوَال/'amwa:l/.

\section{Perubahan / / / / / / / / / و/ / / / / / / / /}

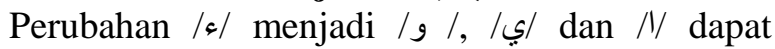
terjadi pada beberapa keadaan sebagai berikut:

a. Dua $/ \varepsilon /$ saling berdampingan sedangkan $/ \varsigma /$ yang ke dua tidak bervokal.

b. $\quad / \& /$ terletak di akhir kata pada mu£annaa, jama mu'annas salim, dan nisbah sedangkan sebelumnya terdapat vokal panjang $/ \%$.

Untuk analisis data pada kategori ini penulis tidak menemukannya dalam beberapa rubrik di majalah Alo Indonesia edisi 108 ini.

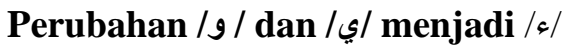

Perubahan و / / dan / menjadi / / / / dapat terjadi pada beberapa keadaan sebagai berikut:

a. $\quad$ / و / sebagai K3 dan terletak setelah vokal panjang // pada pola fa`a:lun, fu'a:lun, dan fia:lun. Fa: 'ilun dan sigah muntaha al-jumu' dengan pola fa'a:'ilu.

b. / / / san sebagai K2 dan didahului vokal panjang /// pada pola fa: 'ilun.

c. إي/ terletak setelah vokal panjang /I pada sigah muntaha al-jumu dengan pola fa'a:'ilu:
Berikut adalah analisis data yang penulis temukan dalam beberapa rubrik di majalah Alo Indonesia edisi 108:

Tabel 5. Kata-Kata yang Penulis Temukan di Rubrik Majalah ALO no.108 Perubahan/و/ / dan/menjadi $|\&|$

\begin{tabular}{|c|c|c|}
\hline No & Bentuk asli & Halaman \\
\hline 10 & /لدَائِحَة /da:'imah/ & $\begin{array}{c}\text { hlm. } 6 \text { kolom } 1 \\
\text { baris } 4\end{array}$ \\
\hline 11 & 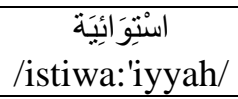 & $\begin{array}{c}\text { hlm. } 6 \text { kolom } 2 \\
\text { baris } 1\end{array}$ \\
\hline 12 & شَرَاءُ شِsyira:'un/ & $\begin{array}{c}\text { hlm. } 13 \text { kolom } 1 \\
\text { baris } 22\end{array}$ \\
\hline
\end{tabular}

kata دَائمَن /da:'imah/ dalam (10) merupakan ism fa:'il dari bentuk ma:di دَا 1 Ida:mal yang memiliki akar دوم /DWM/ (Taher 2011: 136). Akar tersebut mengikuti pola fa: $i l$ sehingga

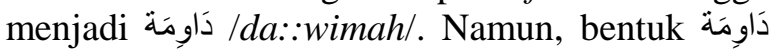
/da:wimah/ tidak disepakati kemunculannya oleh para ahli bahasa Arab melainkan menggantinya dengan bentuk دَائَِحَة/da:'imah/. Pada kasus ini, yang terjadi adalah perubahan konsonan /w/ menjadi konsonan / / /. Ini dapat terjadi karena dalam fonologi bahasa Arab, konsonan /w/ yang menempati $\mathrm{K} 2$ dan didahului oleh vokal panjang // harus diganti dengan konsonan /\&/. Maka, hasilnya adalah dari bentuk da:wimah berubah menjadi bentuk da्:'imah.

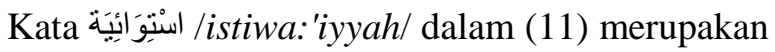
bentuk masdar dari bentuk ma:di اسنتََّى /istawaal yang merupakan hasil derivasi dari bentuk madi سَوَى /sawa:/. Adapun kata سَوَى /sawa:/ memiliki akar س و ـ/SWY/ (Taher 2011: 203). Akar tersebut mengikuti pola iftia:liyyah sehingga

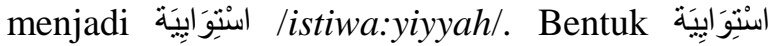
/istiwa:yiyyah/ tidak diizinkan muncul karena kehadiran استنِتَائَيَتَ /istiwa:'iyyah/. Proses

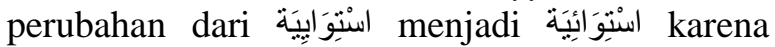
posisi /y/ yang menempati K3 serta didahului oleh vokal panjang /// sehingga konsonan /y/ harus diganti dengan konsonan hamzah /s/. Proses tersebut menghasilkan kata istiwa:'iyyah.

Kata شِرَاءُ /syira:'un/ dalam (12) merupakan bentuk masdar dari bentuk $m \pm i$ شَرَير /syara:/ serta memiliki akar ش ري /Sy R Y/ (Taher 2011: 213). Akar tersebut mengikuti pola fi a:lun 
sehingga seharusnya menjadi شِيَّرَيْ /syira:yun/. Namun, bentuk شِرَاي" /syira:yun/ tidak ditemukan dalam bahasa Arab karena diblok oleh kata شَرَاء /syira:'un/. Pada kasus ini, yang terjadi adalah perubahan konsonan /y/ menjadi konsonan hamzah /\&/. Ini dapat terjadi karena dalam fonologi bahasa Arab, konsonan /y/ yang menempati K3 dan didahului oleh pemanjanan vokal /a/ pada K2, sehingga konsonan /y/ harus diganti dengan konsonan hamzah /\&/. Dari proses tersebut terjadilah perubahan dari bentuk syira:yun menjadi syira:'un.

\section{Al-'I lal bi Al-Hazf (Pelesapan)}

i lal bi al-hazf terbagi menjadi empat bagian yaitu: (1) pelesapan bunyi $/ g /$, (2) pelesapan bunyi /ي/, (3) pelesapan bunyi /// dan (4) pelesapan bunyi $/ ء /$.

\section{Pelesapan bunyi / / /}

Pelesapan /g / dapat terjadi pada beberapa keadaan sebagai berikut:

a. Ig / sebagai K1 pada verba muda:ri berpola yaf ilu dan verba $a m r$ berpola if il.

b. /g / sebagai K2 tak bervokal dan bersandingan dengan $\mathrm{K} 3$ yang tak bervokal. Hal ini terjadi pada verba madi dan verba $a m r$ yang bersanding dengan pronomina persona.

c. $/ g /$ sebagai K3 pada verba verba $a m r$.

d. /g / sebagai K3 tak bervokal terletak sebelum / / mukhatabah.

Berikut adalah data yang ditemukan dalam beberapa rubrik di majalah Alo Indonesia edisi 108:

Tabel 6. Kata-Kata yang Penulis Temukan di Rubrik Majalah ALO no.108 Pelesapan bunyi /و/

\begin{tabular}{|c|c|c|}
\hline No & bentuk asli & halaman \\
\hline 13 & /tajidu/ تَجِدُ / & $\begin{array}{c}\text { hlm. } 6 \text { kolom } 1 \text { baris } \\
9\end{array}$ \\
\hline 14 & كُنَ / / kuntul & $\begin{array}{l}\text { hlm. } 11 \text { kolom } 1 \\
\text { baris } 5\end{array}$ \\
\hline
\end{tabular}

Kata نَدajidu/ dalam (13) merupakan verba muda:ri dari bentuk ma:di وَجَد /wajadal yang memiliki akar وج د/WJD/ (Taher 2011: 459). Akar tersebut mengikuti pola yafilu sehingga menjadi يَوْدُ /yawjidu/. Namun, bentuk yang lebih produktif digunakan adalah تَجْدُ /tajidu/.
Bentuk تَوْجند /yawjidu/ tidak diizinkan muncul karena kehadiran تَجْدُ /tajidu/. Proses perubahan

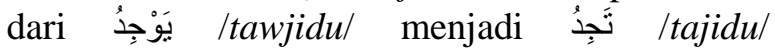
dikarenakan posisi /w/ yang menempati K1 dan terletak diantara prefiks bervokal /a/ dan K2 bervokal /i/, sehingga konsonan /w/ harus dilesapkan. Adapun hasilnya adalah terciptanya bentuk tajidu yang sebelumnya adalah tawjidu.

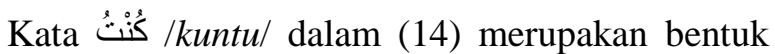
infleksi dari verba madi كَانَ /ka:nal yang memiliki akar i s /KWN/. Akar tersebut mengikuti pola fa`altu sehingga menjadi كَتْنَ /kawantu/. Namun, aturan ini tidak disepakati karena verba madi yang berpola fa ‘ala dimana /w/ berposisi sebagai K2 serta diiringi dengan konsonan tak bervokal, maka K1 akan bervokal /u/ dan vokal pada K2 akan dilesapkan Al Galayayn (2008:203), sehingga menjadi /kuwntal. Akan tetapi, bentuk كُونْتَ /kuwntu/ tidak diizinkan muncul dalam bahasa Arab karena

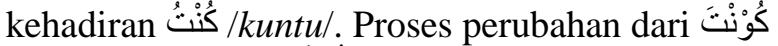

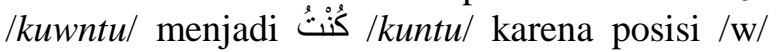
yang menempati $\mathrm{K} 2$ serta tak diiringi vokal bersanding dengan konsonan tak bervokal tidak berterima dalam artikulasi bahasa Arab, sehingga /w/ harus dilesapkan dan menghasilkan bentuk kuntu.

\section{Pelesapan bunyi /ي /}

Pelesapan / / dapat terjadi pada beberapa keadaan sebagai berikut:

a. $\quad /$ menempati K2 yang tidak bervokal dan bersandingan dengan K3 yang tak bervokal. Hal ini terjadi pada verba $a m r$ dan verba madi yang bersanding dengan domir,

b. /ي / sebagai K3 pada verba $a m r$.

c. اي/ sebagai K3 pada verba mudari bersanding dengan / / jama $a h$.

Berikut adalah analisis data yang penulis temukan dalam beberapa rubrik di majalah Alo Indonesia edisi 108:

Tabel 7. Kata-Kata yang Penulis Temukan di Rubrik Majalah ALO no.108 Pelesapan bunyi /ي/

\begin{tabular}{ccc}
\hline No & Bentuk asli & Halaman \\
\hline 15 & ín & hlm. 15 kolom 1 \\
& lyaqdu:nal & baris 5 \\
\hline
\end{tabular}


Kata يَقْضُوْن /yaqdu:nal dalam (15) merupakan hasil infleksi dari bentuk mudari يَقْضِي (1yaqdi:/ serta memiliki akar kata ف ض ي (Taher 2011: 339). Akar tersebut mengikuti pola yaf iluuna sehingga menjadi يَْضِيُوْن /yaqdiyu:nal. Namun, bentuk بَفْضِيُوْن /yaqdiyu:na/ tidak disepakati oleh para ahli bahasa Arab dan menggantinya dengan bentuk يَقْضُوْن /yaqdu:nal. Pada kasus ini yang terjadi adalah pelesapan konsonan /y/. Ini dapat terjadi karena posisi /y/ yang menempati K3 bertemu dengan sufiks /w/ jama ah yang sifatnya permanen, sehingga konsonan /y/ harus dilesapkan dan menghasilkan bentuk يَقْضِنْنِ Adapun perubahan vokal /i/ yang mengiringi K2 menjadi /u/ dikarenakan adanya sufiks /w/ yang tidak dapat diganti keberadaannya dengan konsonan lain, sehingga menghasilkan bentuk يَقْضُوْن /yaqdu:nal.

\section{Pelesapan bunyi ///}

Sebagaimana yang telah penulis paparkan pada bab sebelumnya. Bahwa terjadinya pelesapan // / dapat terjadi pada beberapa keadaan sebagai berikut:

a. // berperan sebagai hamzah wasl pada verba dan didahului oleh prefiks.

Berikut adalah analisis data yang penulis temukan dalam beberapa rubrik di majalah Alo Indonesia edisi 108:

Tabel 7. Kata-Kata yang Penulis Temukan di Rubrik Majalah ALO no.108 Pelesapan bunyi ///

\begin{tabular}{ccc}
\hline No & Bentuk asli & Halaman \\
\hline 16 & imisytahirul & $\begin{array}{c}\text { hlm. } 8 \text { kolom } 1 \\
\text { baris } 27\end{array}$ \\
\hline 17 & Imuntasyirah/ & $\begin{array}{c}\text { hlm. } 15 \text { kolom } 1 \\
\text { baris } 11\end{array}$ \\
\hline
\end{tabular}

Kata نَتْنَّهُ /tasytahirul dalam (16) merupakan verba mudari dari bentuk madi انَتَنَرَ /isytaharal

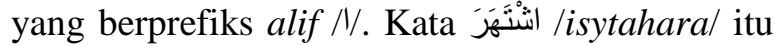
sendiri merupakan derivasi dari bentuk madi شَهَرَ /syaharal yang memiliki akar kata $\lrcorner$ o ش/SHR/ (Taher 2011: 220). Akar tersebut mengikuti pola

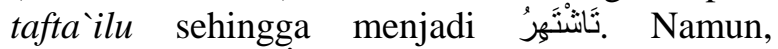
pemunculan تَانْنَّه keberadaan bentuk نَتَنْنَهْرُ Peristiwa ini dapat terjadi dikarenakan posisi /// sebagai hamzah wasl bertemu dengan $\mathrm{K} 1$ yang tak bervokal tidak berterima dalam artikulasi bahasa Arab. Oleh karena itu, keberadaan alif /// harus dilesapkan sehingga menghasilkan bentuk تَتَتْنَهُرْ /tasytahirul yang sebelumnya adalah تَأَتْنَهُ /tasytahirul

Kata مَنْنَتَبرَ /muntasyirah/ dalam (17) merupakan bentuk ism fa: îil dari bentuk madi انْتَشَرَ lintasyaral yang juga merupakan hasil derivasi

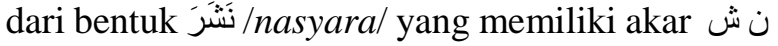
Ј INSR/ (Taher 2011: 421). Akar tersebut mengikuti pola mufta ilatun sehingga menjadi

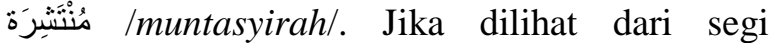
keutuhannya, seharusnya menjadi مُانتَتَّرَة . Namun, bentuk مُانتَتَرَرَة tidak diizinkan muncul karena diblok oleh bentuk مُنْتَتِرَة /muntasyirah/. Hal ini dikarenakan porisi alif / / sebagai prefiks bersandingan dengan $\mathrm{K} 1$ yang tak bervokal, sehingga alif // / harus dilesapkan. Hasilnya adalah terciptanya bentuk مُنْتَتِرَرَة /muntasyirah/

\section{Pelesapan bunyi $/ \& /$}

Sebagaimana yang telah penulis paparkan pada bab sebelumnya, pelesapan $/ \varsigma /$ dapat terjadi pada beberapa keadaan sebagai berikut:

a. $\quad / \varsigma /$ berperan sebagai prefiks yang bertemu أ، ت، () (ن) atau jatuh setelah prefix lainnya.

b. $/ \& /$ berperan sebagai K2 dan bersanding dengan semivokal sebagai K3 pada verba imperfektum

Berikut adalah analisis data yang ditemukan dalam beberapa rubric di majalah Alo Indonesia edisi 108:

Tabel 8. Kata-Kata yang Penulis Temukan di Rubrik Majalah ALO no.108 Pelesapan bunyi / $\&$ /

\begin{tabular}{ccc}
\hline No & Bentuk asli & Halaman \\
\hline 18 & sُرْثِد /mursyid/ & hlm. 10 kolom 1 baris \\
& & 4 \\
\hline
\end{tabular}

Kata مُرْشِد /mursyid/ dalam (18) merupakan bentuk amr dari bentuk madi أَرْنَ learsyadal yang merupakan hasil derviasi dari bentuk madi رَشَدَ /rasyadal serta memiliki akar رش د /RSD/ (Taher 2011: 154). Pada hakikatnya dari bentuk madi أَرْشَ /?arsyadal jika diubah menjadi bentuk ism fa:`il seharusnya menjadi مُأْرْنِدn /mu? rsyidul. Namun, bentuk مُأْرَثِدُ /mu'rsyidu/ tidak disepakati oleh para ahli bahasa Arab melainkan menggantinya dengan bentuk مُرْنِّد /mursyid/. 
Pada kasus itu, yang terjadi adalah pelesapan konsonan hamzah $/ \& /$ yang disebebakan oleh adanya K1 tak bervokal sehingga sulit diucapkan. Oleh sebab itu, konsonan hamzah /\&/ harus dilesapkan, sehingga menghasilkan bentuk مرْتِثَد Imursyid/.

\section{I lal bi Al-Taskin (Pelesapan vokal)}

Sebagaimana yang telah dipaparkan pada bab sebelumnya, proses pelesapan vokal dapat terjadi jika/g/dan / / berposisi sebagai K3 dan jatuh setelah vokal /u/ atau /i/. Berikut adalah beberapa kata yang ditemukan dalam Alo Indonesia edisi 108.

Tabel 9. Kata-Kata yang Penulis Temukan di Rubrik Majalah ALO no.108 Yang Mana Terdapat Pelepasan Vokal

\begin{tabular}{|c|c|c|}
\hline No & Bentuk asli & Halaman \\
\hline 19 & تكِفِي /takfi:/ & $\begin{array}{c}\text { hlm. } 6 \text { kolom } 1 \text { baris } \\
6\end{array}$ \\
\hline 20 & /tabdu:/ تَبْدُو & $\begin{array}{c}\text { hlm. } 8 \text { kolom } 1 \text { baris } \\
15\end{array}$ \\
\hline
\end{tabular}

Kata نَكِفِ /takfi:/ dalam (19) merupakan verba mudari dari bentuk madi كَفَى /kafa:/ yang memiliki akar ك ف ـ كFFI (Taher 2011: 362). Akar kata tersebut mengikuti pola tafilu sehingga menjadi تَكِفِيُ /takfiyu/. Namun, bentuk Itakfiyul tidak diizinkan muncul karena kehadiran تكَفِي /takfi:/. Pada kasus tersebut yang terjadi adalah melesapnya vokal /u/ yang mengiringi konsonan /y/ yang menempati K3. Hal ini dikarenakan adanya vokal /i/ yang mendahului konsonan /y/, sehingga konsonan /y/ berubah menjadi pemanjangan vokal /i/ yang mengharuskan pelesapan vokal /u/ yang mengiringi konsonan /y/.

Kata بَتَبُْ /tabdu:/ dalam (20) merupakan verba mudari dari bentuk madi بَ /bada:/ yang memiliki akar ب د و /BDW / (Taher 2011: 18). Akar tersebut mengikuti pola taf ulu sehingga

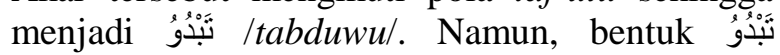
Itabduwul tidak ditemukan dalam bahasa Arab karena terblok oleh kata تَبْدُ /tabdu:/. Pada kasus ini yang terjadi adalah melesapnya vokal /u/ yang mengiringi konsonan /w/ yang menempati K3. Ini dapat terjadi karena dalam fonologi bahasa Arab, konsonan /w/ yang menempati K3 serta didahului oleh vokal /u/, maka konsonan /w/ harus diganti dengan pemanjangan vokal /u/ tersebut dan melesapkan vokal /u/ yang mengiringi konsonan /w/ tersebut.

\section{Al-'I lal bi Al- Naql (Pemindahan vokal)}

اي/ Perpindahan vokal yang menyertai dan dapat terjadi jika keduanya berposisi sebagai K2 dan didahului oleh konsonan tak bervokal. Berikut adalah analisis data yang ditemukan dalam beberapa rubrik di majalah Alo Indonesia edisi 108.

Tabel 10. Kata-Kata yang Penulis Temukan di Rubrik Majalah ALO no.108 Yang Mana Terdapat Pemindahan Vokal

\begin{tabular}{|c|c|c|}
\hline $\mathrm{No}$ & Bentuk asli & Halaman \\
\hline 21 & تَنِيْعِ /tabi:`ul & hlm. 13 kolom 2 baris 7 \\
\hline 22 & $\begin{array}{c}\text { تَعَوُْدُ } \\
\left|t a^{\prime} u: d u\right|\end{array}$ & hlm. 6 kolom 2 baris 11 \\
\hline
\end{tabular}

Kata نَيَيْ /tabi:`u/ dalam (21) merupakan verba mudari dari bentuk madi lba:`al yang

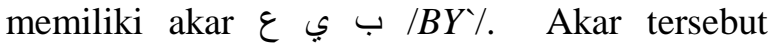
mengikuti pola tafilu sehingga menjadi تَبْيُع ع Itabyi u/. Namun, bentuk نَيْيِ /tabyi u/ tidak disepakati oleh para ahli bahasa Arab melainkan menggantinya dengan bentuk تَنْيَ /tabi: 'u/. proses perubahan ini dapat terjadi karena posisi /y/ yang menempati K2 serta diiringi vokal bersanding dengan K1 yang tak bervokal, sehingga vokal tersebut harus dipindahkan ke K1, maka terciptalah bentuk تَنِيْيُ.

Verba تَعُوُْو/ta'u:du/ dalam (22) merupakan verba mudari dari bentuk madi عَادَ I'a:dal yang memiliki akar د ا ع /WD/ (Taher 2011: 280). Akar tersebut mengikuti pola taf ulu sehingga menjadi تَعَوْوُدُ تَعْوُدُ /ta'wudu/. Namun, bentuk /ta'wudul tidak diizinkan muncul karena

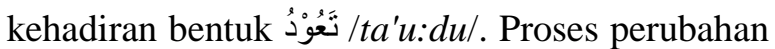

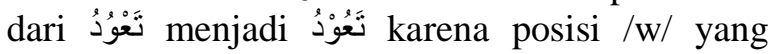
menempati K2 serta didahului oleh K1 tak bervokal, sehingga vokal /u/ pada konsonan /w/ harus dipindahkan ke $\mathrm{K} 1$ dan hasilnya adalah تنَعُوْدُ

\section{Al-'I lal bi Al-Naql wa Al-Qalb}

Proses pemindahan vokal serta dilanjutkan dengan adanya proses perubahan dari semivokal 
ke semivokal lainnya dapat terjadi pada beberapa kasus sebagai berikut:

a. / / dan bervokal /a/ dan berposisi sebagai K2 sedangkan sebelumnya merupakan K1 tak bervokal.

b. /gervokal /i/ dan berposisi sebagai K2 yang didahului oleh konsonan tak bervokal.

Berikut adalah analisis data yang ditemukan dalam beberapa rubric di majalah Alo Indonesia edisi 108.

Tabel 11. Analisis Data yang Ditemukan dalam Beberapa Rubric di Majalah alo Indonesia edisi 108

\begin{tabular}{|c|c|c|}
\hline No & bentuk asli & Halaman \\
\hline 23 & مَقَاْمُ & hlm. 7 kolom 1 baris 20 \\
\hline 24 & 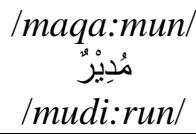 & $\begin{array}{c}\text { hlm. } 20 \text { kolom } 3 \text { baris } \\
29\end{array}$ \\
\hline
\end{tabular}

Kata مَفَامَ /maqa:mun/ dalam (23) merupakan ism makan dari bentuk madi قََ lqa:mal yang memiliki akar ق و /QWM/ (Taher 2011: 348). Akar tersebut mengikuti pola maf alu sehingga seharusnya menjadi مَفْوَمُ /maqwamul. Namun, bentuk yang lebih produktif digunakan adalah /maqa:mun/. Pada kasus itu, yang terjadi adalah pemindahan vokal dan perubahan konsonan $/ \mathrm{w} /$ menjadi pemanjangan vokal /a/ pada K1. Ini dapat terjadi karena posisi /w/ yang menempati K2 serta bervokal didahului oleh K1 tak bervokal, sehingga vokal /a/ yang menyertai konsonan /w/ harus dipindahkan ke K1, maka terciptalah kata مَقَوْمُ Kemudian pada bentuk tersebut posisi /w/ sebagai K2 yang didahului oleh vokal /a/, harus diganti dengan pemanjangan vokal /a/ pada K1, maka terciptalah bentuk مَقَمَ.

Kata مُدِيْرِ /mudi:run/ dalam (24) merupakan isim

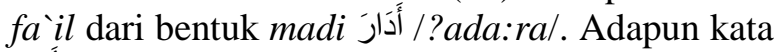
دَارَ I /da:ral yang memiliki akar دور /DWR/ (Taher 2011: 135). Akar tersebut mengikuti pola mufilu

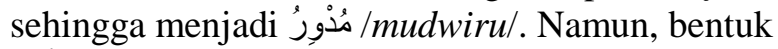
مُدْوِرُ /mudwiru/ tidak disepakati oleh para ahli bahasa Arab melainkan menggantinya dengan bentuk مُدِيْرِ /mudi:run/. Proses perubahan dari

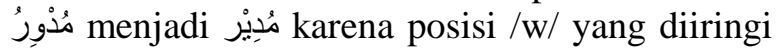
vokal dan menempati K2 serta sebelumnya terdapat K1 tak bervokal, sehingga vokal pada
$\mathrm{K} 2$ harus dipindahkan ke $\mathrm{K} 1$, maka terciptalah kata مُدْوْرِ Setelah itu, posisi /w/ yang menempati K2 serta didahului oleh vokal /i/ mengharuskan /w/ diganti dengan pemanjangan vokal /i/ pada K1 tersebut, sehingga menghasilkan bentuk مُدِيْر.

\section{Al-'I lal bi Al-Naql wa Al- Hadf (Pemindahan dan Pelesapan)}

Proses pemindahan vokal serta dilanjutkan dengan adanya proses pelesapan semi vokal dapat terjadi jika / / bervokal /u/ dan / bervokal /i/ serta berposisi sebagai K2 yang terletak di antara dua bunyi tak bervokal. Adapun data yang mendukung proses ini, tidak ditemukan dalam majalah Alo Indonesia edisi 108.

\section{Al-'Tla:l bi Al-Naql wa Al-Qalb wa Al- Hadf (Pemindahan, Penggantian, dan Pelesapan)}

Proses pemindahan vokal serta dilanjutkan dengan adanya proses perubahan dan pelesapan semi vokal dapat terjadi jika /w/ berposisi sebagai K2 bervokal /a/ atau /i/ dan terletak di antara dua konsonan tak bervokal.

Berikut adalah analisis data yang ditemukan dalam beberapa rubric di majalah Alo Indonesia edisi 108 .

Tabel 12. Analisis Data yang Ditemukan dalam Beberapa Rubric di Majalah Alo Indonesia edisi 108

\begin{tabular}{|c|c|c|}
\hline $\mathrm{No}$ & Bentuk asli & Halaman \\
\hline 25 & إِقَاَتة & hlm. 6 kolom 1 \\
\hline \multirow{3}{*}{26} & /'iqa:mah/ & baris 10 \\
\hline & & hlm. 8 kolom 2 \\
\hline & /'ida:fah/ & baris 3 \\
\hline
\end{tabular}

Kata إِقَامَة /'iqa:mah/ dalam (25) merupakan bentuk masdar dari bentuk madi أََََ /?aqa:mal. Adapun kata أََََ /?aqa:mal merupakan derivasi

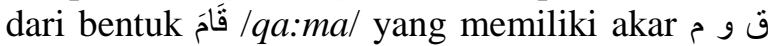
IQWMI (Taher 2011: 348). Akar tersebut mengikuti pola 'if a:latun seharusnya menjadi

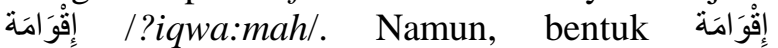
/?iqwa:mah/ tidak ditemukan dalam bahasa Arab karena diblok oleh kata إقَََامَة l?iqa:mah/. Pada kasus itu, yang terjadi adalah perpindahan vokal pada konsonan /w/ ke K1 serta perubahan konsonan /w/ menjadi pemanjangan vokal /a/ dan kemudian konsononan /w/ dilesapkan. 
Hal ini dapat terjadi karena posisi /w/ yang menempati K2 serta bervokal didahului oleh K1 tak bervokal, sehingga vokal /a/ yang menyertai konsonan /w/ harus dipindahkan ke K1, maka terciptalah kata إِقَُْْامَة. Kemudian pada bentuk tersebut posisi /w/ sebagai K2 yang didahului oleh vokal /a/, harus diganti dengan pemanjangan vokal /a/ pada K1, maka terciptalah bentuk إقَاِامَة. Adapun bertemunya dua alif /// yang berurutan dalam fonologi bahasa Arab tida berterima dalam artikulasi bahasa Arab, sehingga salah satunya harus dilesapkan, maka terciptalah kata إقََاَْة.

Kata إضضَافَة /'ida:fah/ dalam (26) merupakan bentuk masdar dari bentuk madi أَضَافَ /'ada:fal. Adapun kata أضَّاف /'ada:fal merupakan derivasi

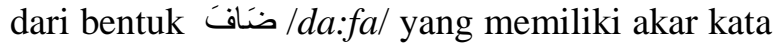
ض ض في ف DYF/ (Taher 2011: 243). Akar tersebut mengikuti pola ?if a:lu sehingga menjadi إضِيََافَة /'idya:fah/. Namun, bentuk إضضنََافَة tidak diizinkan muncul karena kehadiran bentuk إِضَافَة perubahan dari إضِنَافَة menjadi karena posisi /y/ yang menempati K2 disertai vokal /a/ serta didahului oleh $\mathrm{K} 1$ tak bervokal, sehingga vokal yang mengiringi / $\mathrm{y} /$ harus dipindahkan ke K1 dan erciptalah kata إِضَيْافَة. Kemudian pada bentuk tersebut posisi /y/ sebagai K2 yang didahului oleh vokal $/ \mathrm{a} /$, harus diganti dengan pemanjangan vokal /a/ pada K1, maka terciptalah bentuk إِضَافِة. Adapun bertemunya dua alif // yang berurutan dalam fonologi bahasa Arab tidak berterima dalam artikulasi bahasa Arab, sehingga salah satunya harus dilesapkan, maka terciptalah

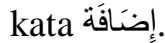

\section{SIMPULAN DAN SARAN}

\section{Simpulan}

Semua bentuk perubahan kata dalam bahasa Arab selalu mengikuti aturan yang baku dan terstandar. Sekalipun ada banyak bentuk kata yang dihasilkan dari proses derivasi dan infleksi dengan mengikuti pola-pola yang tidak baku, pola-pola yang tidak baku tersebut, jika dicermati tetap menggunakan kaidah dan pola. Hanya saja pola-pola tersebut "menyimpang" dari pola yang baku.

I lal merupakan salah satu topik kajian para linguist Arab tentang perubahan morfologis yang terjadi pada hamzah atau salah satu huruf illat ( ، ي) و، Namun, setelah ditelaah lebih dalam, kajian I'lal sangat erat kaitannya dengan block factor dalam sistem morfologi bahasa Arab seperti yang telah dijelaskan pada bab sebelumnya.

Setelah melakukan analisis, ditemukan 247 kata dalam majalah Alo Indonesia vol 108 edisi MeiJuni 2014. Temuan tersebut berjumlah 247 kata, yang dikelompokkan menjadi tujuh macam $i$ lal sebagai berikut: (1) i la:l bi al-qalb terdapat $124 \mathrm{kata}$, (2) i la:l bi al-hadf terdapat 56 kata, (3)i 'la:l bi al-taskin terdapat 9 kata, (4) i la:l bi al-naql terdapat $21 \mathrm{kata},(5)$ i la:l bi al-naql wa al-qalb terdapat $27 \mathrm{kata}$, dan (6) i la:l bi al-naql wa al-hazf, tidak ditemukan dalam data, dan (7) i 'la:l bi al-naq, wa qalb wa alhazf, terdapat pada 10 kata.

\section{Saran}

Topik ini merupakan kajian yang sangat menarik. Dengan data yang lebih luas dan dengan bidang yang lebih beragam, penelitian akan lebih banyak menemukan bentuk-bentuk kata yang tergolong kompleks dalam bahasa Arab.

Selain itu, yang juga perlu diperdalam adalah alasan filosofis dan fonologis yang melatari setiap kaidah pola yang tidak baku tersebut. Penelitian berikutnya akan sangat bermanfaat, apabila dapat mengungkap perihal sosiopragmatik dari masing-masing pola yang tidak baku namun lebih produktif digunakan, dibanding pola yang sudah baku

\section{DAFTAR PUSTAKA}

[1] Hockett, C. 2004. "Two Models of Grammatical Description" in Morphology: A Critical Concept in Linguistics. London: Routledge

[2] Holes, Clive. 1994. Modern Arabic: Structures, Functions, and Varieties. London: Longman

[3] Majalah "Alo Indonesia" volume 108, edisi Mei-Juni tahun 2014

[4] Hasan, Abbas. 1974. Al-Nahwu al-Wa:fi. Mesir: Daru al-Ma`a:rif. 
[5] Nu'mah, Fuad. Tt. Mulakhos Qawaidul Lughah Al Arabiyyah. Suriah: Maktabah Al Hidayah

[6] Abboud, Peter F. 1986. Elementary Modern Standard Arabic 2. London: Cambridge University Press.

[7] El Dahdah, Antonie. 1981. A Dictionary of Arabic Grammar in Charts and Tables. Libanon: Maktabah Lubnan.

[8] Al-Jarim, Ali dan Musthafa Amin. 2010. Al-Nahwu al-Wa:dih fi Qawa:`id al-Lugah al-`Arabiyyah. Kairo: D \pm ru al-Ma`a:rif.

[9] Kholisin. 2001. Tesis: Asimilasi Dalam Bahasa Arab (Sebuah Kajian Morfofonemik). Jakarta: Universitas Indonesia.

[10] Taqiyah, Aminatut. 2008. Al-'Tla:l wa al'Ibda:l fi S-rah al-'Ahqa:f (Dira:sah Tahli:liyah Sarfiyyah). Yogyakarta: UIN Sunan Kalijaga Yogyakarta

[11] Irawan, Jaya Putra. 2011. Ibdal dalam Bahasa Arab: Tinjauan Morfofonemik.Yogyakarta: Universitas Gajah Mada.

[12] Michael Rows. 2013. Productivity in English Morphological Processes. Master Thesis.
[13] Chaer, Abdul. 2012. Linguistik Umum. Jakarta: Rineka Cipta

[14] Verhaar, J.W.M. 2010. Asas-Asas LInguistik Umum. Yogyakarta: Gadjah Mada University Press.

[15] Hidayatullah, Moch. Syarif. 2012. Cakrawala: LInguistik Arab. Jakarta: AlKitabah.

[16] Haywood, J.A. dan Nahmad. H.M. 1965. New Arabic Grammar of the Written Language. London: Percy Lund Humphries.

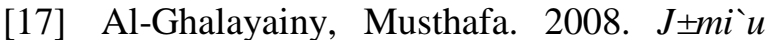
Al-Duru:s Al-'Arabiyyah. Mesir: Maktabah al-Syuruq al-Dauliyyah.

[18] Jensen, John T., 1990. Morphology, Word Structure in Generative Grammar. Amsterdam: John Benyamin

[19] Munawwir, Ahmad Warson. 1997. Kamus Al-Munawwir Arab-Indonesia. Surabaya: Pustaka Progressif.

[20] Wehr, Hans. 1982. Dictionary of Modern Written Arabic: Arabic-English. Beirut: Mc. Donald \& Evan.

[21] Fayadh, Sulaiman. 1995. Al-Nahwu al'Asry. Mesir:_Markaz al-'Ahram. 